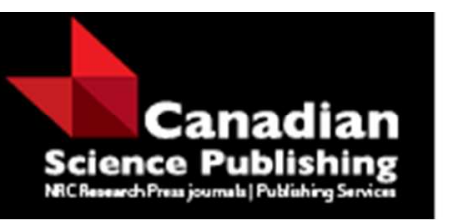

Environmental Reviews Dossiers environnement

\title{
Artificial floating islands for water quality improvement
}

\begin{tabular}{|c|c|}
\hline Journal: & Environmental Reviews \\
\hline Manuscript ID & er-2016-0038.R3 \\
\hline Manuscript Type: & Review \\
\hline Date Submitted by the Author: & 20-Mar-2017 \\
\hline Complete List of Authors: & $\begin{array}{l}\text { Chang, Yueya; East China Normal University, School of Ecological and } \\
\text { Environmental Sciences } \\
\text { Cui, He; East China Normal University, School of Ecological and } \\
\text { Environmental Sciences } \\
\text { Huang, Minsheng; East China Normal University, School of Ecological and } \\
\text { Environmental Sciences } \\
\text { He, Yan; East China Normal University, School of Ecological and } \\
\text { Environmental Sciences }\end{array}$ \\
\hline Keyword: & $\begin{array}{l}\text { artificial floating island, applications, factors, constructed wetlands, } \\
\text { performances }\end{array}$ \\
\hline
\end{tabular}

\section{SCHOLARONE Manuscripts}




\section{Artificial floating islands for water quality improvement}

\section{Yueya Chang, He Cui, Minsheng Huang, Yan He}

3 Abstract: Artificial floating islands (AFIs) are variation of wetland treatment systems for water

4 quality improvement. This paper provides a review concerning AFIs in terms of their development,

5 classification and applications in the removal of nutrients, heavy metals and chemical oxygen

6 demand (COD) on waterways. The role of microorganisms, aquatic plants and aquatic animals in

7 AFIs for water decontamination and purification was also discussed. Additionally, some key

8 factors influencing the AFIs' performances were discussed and comparisons between AFIs and constructed wetlands were reviewed. Finally, further perspectives of artificial floating islands were identified to possibly improve their performances. The understanding of the mechanisms in AFIs that drive removal of various contaminants to improve water quality is crucial, which were also highlighted in this paper.

Key words: artificial floating islands; applications; factors; constructed wetlands; performances

\section{Introduction}

\subsection{Definition}

Artificial floating islands (AFIs) are constructed with three layers, namely, the upper leaf and the stem of plants, the middle floating body and the bottom root system including the related ecological communities such as algae, biofilms, zooplankton, and other small invertebrates.

Beneath the bottom layer exists a free-water zone (or water column) whose depth varies with the water level of the water body. A layer of organic sludge develops under the free-water zone over

Y.Y. Chang, H. Cui, M.S. Huang, and Y. He. School of Ecological and Environmental Sciences, East China Normal University, 500 Dong Chuan Road, Shanghai 200062, PR China.

Corresponding author: Minsheng Huang (Tel.: +86 13651814239 Email-address: mshuang@des.ecnu.edu.cn). 
the native subsurface material. Fig. 1, as adopted from Harding (2009), shows a schematic drawing of a typical natural floating island consisting of a thick floating organic mat that supports the growth of plants.

\subsection{History}

The first ecological floating island was believed to be developed in Europe for the riparian ecosystem, rather than for the water quality purification. Until the 1980s, the first artificial floating island was built by Germans to remove silver, cobalt and strontium from polluted waters using water hyacinth (Eichhornia crassipes) and alligator weeds (Alternanthera philoxerides)

(Wolverton and Mcdonald, 1975). Constructed floating islands were developed in Japan in the 1990s, with Canna generalis being grown in floating beds to absorb nutrients from fish ponds and treatment basins (Wu et al., 2000). Twenty percent coverage of soil-less artificial floating islands, again using Canna generalis, was later recommended to improve water quality in China (Bing and Chen, 2001).

Traditional floating islands mainly depend on plant uptake and microbial metabolism for the removal of pollutants. While limited by the aquatic plant quantity, the plant root surface area and microbial species associated with the root, the removal efficiencies of chemical oxygen demand (COD) and other pollutants are relatively low. Subsequently, some scholars combined various auxiliary technologies with traditional floating islands to enhance the purification capacity that lead to the formation of some new types of ecological floating islands.

In China, Li et al. (2009) found that a micro-aerated floating island can remove the pollutants by $70 \%$ under the condition of inflow $6000 \sim 10000 \mathrm{~m}^{3} / \mathrm{d}$ and total aeration $50 \mathrm{~m}^{3} / \mathrm{h}$. Zhang et al. (2011) treated rural sewage containing initial concentrations of COD of $161.58 \mathrm{mg} \mathrm{L}^{-1}$, total 
nitrogen (TN) $40.31 \mathrm{mg} \mathrm{L}^{-1}$ and total phosphorus (TP) $2.68 \mathrm{mg} \mathrm{L}^{-1}$, using the combined biological purification tank-enhanced ecological floating raft system that effectively removed COD, TN and TP by $79.59 \%, 61.06 \%$ and $77.14 \%$, respectively. Wang et al. (2012) integrated aquatic plants (Ipomoes aquatica), filter-feeding aquatic animals (Hyriopsis cumingii) and artificial medium to treat the lake water, where the aquatic animal and artificial medium enhanced the system removal ability significantly by removing TN, TP, and COD.

\subsection{Classification}

As mentioned above, the traditional floating islands have been developed over the past 30 years, and we can classify the AFIs into three technologies:

\subsubsection{Traditional plant floating island technology}

Traditional plant floating islands, which are composed of higher aquatic plants and a polymer material carrier, which uptake nitrogen $(\mathrm{N})$, phosphorus $(\mathrm{P})$ and other organic compounds in polluted water into parts of the plants. This kind of traditional floating islands can remove the nutrients to some extent, but the efficiency is low. For example, Chen et al. (2010) cultivated Ipomoea aquatica on a traditional artificial floating island to treat intensive aquaculture ponds with twenty percent of coverage. During the 90 days of the experiment, the concentrations of TN and TP were reduced from $8.00 \mathrm{mg} \mathrm{L}^{-1}$ to $5.08 \mathrm{mg} \mathrm{L}^{-1}$ and $0.51 \mathrm{mg} \mathrm{L}^{-1}$ to $0.28 \mathrm{mg} \mathrm{L}^{-1}$, respectively, using this technology, while $52.35 \mathrm{~kg} \mathrm{hm}^{-2}$ of TN and 5.39 of TP were removed with the harvest of Ipomoea aquatica. However, this removal rate was lower compared to other technologies.

Based on the traditional floating island design, Xu et al. (2011) connected three floating islands units with three different plant species, and constructed a staged floating treating wetland (SFTW) to treat malodorous water of an industrial river in Shanghai, where the Hydrocotyle vulgaris unit 
removed the most phosphorus.

\subsubsection{Complex floating island technology}

The complex floating island is a new technology compared to traditional floating islands. It adds "fixed biofilms" or "biocords" as substrates that support the fixed films to purify water through plant absorption, substrate adsorption and microbial association. Complex floating island technology can be separated into two kinds, the combined type and the strengthening type. The combined type increases the artificial medium and aquatic animals to prolong the food chain to form the "plant-aquatic animal-microbe" ecological restoration system for improving the water purification. For example, Xu et al. (2015) established a combined ecological floating bed by hanging the bio-ceramic matrix under the roots of Pistia stratiotes in a pond to treat aquaculture wastewater. As a result of the synergism of plant absorption, matrix adsorption and microorganisms, the removal rates of $\mathrm{TN}$, ammonia nitrogen $\left(\mathrm{NH}_{4}{ }^{+}-\mathrm{N}\right)$, nitrite nitrogen $\left(\mathrm{NO}_{2}{ }^{-} \mathrm{N}\right)$, TP, COD were $52.38 \%, 77.78 \%, 81.97 \%, 67.57 \%$ and $43.98 \%$, respectively. The enhancing type is a new type which adds aeration systems or some specific bacteria. For example, Cui and $\mathrm{Hu}$ (2012) treated WWTP effluent under aeration conditions of dissolved oxygen (DO) of $4.8 \mathrm{mg} / \mathrm{L}$, hydraulic retention time of 1.5 days and water temperature (WT) of 17.8-21.5 $\square$. The removal rates of COD, $\mathrm{TN}$, and $\mathrm{TP}$ were $44.0 \%, 44.9 \%$ and $50.97 \%$, respectively. In addition, the effluent

COD concentration was much lower than the first level A criteria of 'Discharge standard of pollutants for municipal water treatment plant' (GB18918-2002). For example, Li et al. (2009) designed a biological grid device consisting of loaches (Misgurnus anguillicaudatus), Canna plants, biofilms from microorganisms and combined packing to treat polluted river water. The size of the device was $1000 \mathrm{~mm} \times 500 \mathrm{~mm} \times 600 \mathrm{~mm}$, and loaches (Misgurnus anguillicaudatus) were 
put randomly in the device with the density of $1200 \mathrm{~g} \mathrm{~m}^{-3}$. The loach (Misgurnus anguillicaudatus)

excretes special enzymes to decompose special organic substances and increase oxygen supply, and the removal rates of $\mathrm{NH}_{4}{ }^{+}-\mathrm{N}$ and TP were $50.7 \%$ and $82.35 \%$, respectively.

\subsubsection{Moveable floating island-wetland technology}

The moveable floating island-wetland is a combination of wetland and moveable floating island (Zhang et al., 2012). It is a technology based on "matrix filler + ecological bed". In general, it often combines five parts of devices, namely, buoyancy control device, anchoring device, macrophytes bed, microbial bed and aeration device. Hu et al. (2008) selected ceramisites and hydrophilic miner fiber as support materials, Festuca arundinacea as plants to construct a moveable floating island-wetland to treat severely eutrophicated water bodies. During the 34 days of the experiment, the system showed good removal efficiencies, and there was strong nitrification-denitrification in the system. Meanwhile, Shi et al. (2014) also constructed a hybrid system combining plants and rice straw to remove $97.2 \%, 95.4 \%$ and $56.1 \%$ of $\mathrm{NH}_{4}{ }^{+}-\mathrm{N}, \mathrm{TN}$ and TP, respectively.

The AFI has a variety of aliases depending on its scale, complexity, or the preference of those who name it, which includes artificial floating beds/wetlands, floating treatment wetland (FTW), floating plant bed system, integrated floating system, integrated ecological floating bed (IEFB), and so on. For the purpose of this review, however, the authors continue to use the term "artificial floating island (AFI)". Other names will be used only when called for by the reviewed subjects (Naichia et al., 2015).

\section{Applications of AFIs and influence factors}

To date, water pollution is one of the most critical environmental issues, with human 
109

110

111

112

113

114

115

116

117

118

119

120

121

122

123

124

125

126

127

128

129

130

activities adding different types of contaminants (Palma et al., 2010). For example, agricultural

practices are altering water resources as a result of the massive use of fertilizers, pesticides and the

spread of livestock wastes (Huo et al., 2009; Wu et al., 2013). Also industries release large

quantities of heavy metals, organic matters and toxic chemicals to aquatic environments (Islam et

al., 2015). As reported, up to $66 \%$ and $22 \%$ of lakes in China are eutrophic or hyper eutrophic,

respectively (Jin and $\mathrm{Hu}, 2003$ ).

Nitrogen and phosphorus are the two major nutrients affecting water eutrophication, the

heavy metals released into the rivers can be dissolved to form ions or complexes, suspending as

particulate matters or settling down as bed sediments resulted in the loss of water quality, and

some toxic chemicals in water bodies threat aquatic animals or human beings greatly (Tuna et al.,

2007; Stiling, 2011). AFIs have been applied in many such fields, which will be discussed with

the influence factors comprehensively, as there is no published paper available at present

introducing influence factors of AFIs in various applications. These should be considered carefully,

thus, many insights can be gained into the influence factors and applications of AFIs.

\subsection{Nutrient removal and the influence factors}

The main applications of AFIs for nutrient removal strategies are mainly involved in the following:

- Rivers and storm waters (e.g., Sun et al., 2009; Lu et al., 2010; Li et al., 2010; Borne et al., 2014; Jeanette et al., 2015;)

- Industrial wastewater treatment (e.g., Hubbard et al. 2011; Chang et al., 2014)

- Livestock effluents (e.g., Hubbard et al., 2004; Nahlik and Mitsch, 2006)

- Aqua-culture and agriculture (e.g., Nduwimana et al., 2007; Li and Li, 2009) 
131

132

133

134

135

136

137

Macrophytes have been widely applied in AFIs to remove nutrients as oxygen secreted by

plant roots can form many anaerobic-anoxic-oxic micro areas; the situation is equivalent to many

series-parallel $\mathrm{A}^{2} / \mathrm{O}$ units. These units can enhance the function of microbial nitrification and

denitrification and improve nitrogen removal efficiency indirectly. In short, the combination of

plants and microbes will enhance the effect of denitrification. Microbial nitrification and

denitrification were the main nitrogen removal routes. Like nitrogen, phosphorus is a necessary

nutrient for biological growth. However, phosphorus removal in AFIs is not as efficient as it is for biochemical oxygen demand or total suspended solids because removal processes, such as plant uptake, assimilation by microorganisms, adsorption and precipitation, are usually of minor significance (Wang et al., 2016).

The factors influencing AFI results, such as physiochemical, biological and other factors, are shown in detail below.

\subsubsection{Physiochemical conditions}

DO, WT, and $\mathrm{pH}$ are critical physiochemical conditions for an AFI operation. The higher DO would decrease the denitrification, while the lower DO can kill aquatic animals, and the WT affects the activities of bacteria, plants and aquatic animals. $\mathrm{pH}$ should be controlled in the range of 6.5-8.5, and WT should be between 15 and $28 \square$. As these physiochemical factors can influence many physical, chemical and biological processes in the water body, DO should be controlled according to the removal goal, to remove $\mathrm{N}$ only, or to remove other pollutants together (Vymazal, 2007; Luo et al., 2010). For example, Li et al. (2009) developed a micro-aerated AFI with Oenanthe javanica and controlled the $\mathrm{pH}=6.49-8.37, \mathrm{WT}=12.9-20.1 \square, \mathrm{DO}<0.5 \mathrm{ml} / \mathrm{L}$ to remove the high concentration of $\mathrm{NH}_{4}{ }^{+} \mathrm{N}$ in black river water. Chen et al. (2010) planted Ipomoea 
153

154

155

156

157

158

159

160

161

162

163

164

165

166

167

168

169

170

171

172

173

174

aquatica at $20 \%$ coverage with floating rafts and reared some fish in an aquaculture pond. In order to receive a good removal of $\mathrm{N}, \mathrm{P}$, and $\mathrm{COD}$, the $\mathrm{pH}=7.2 \sim 7.8$ and $\mathrm{DO}=7.05 \sim 8.04$ were controlled.

\subsubsection{Island coverage}

Island coverage is an extremely important factor, as floating islands can restrict oxygen diffusion from the air into the water (Smith and Kalin, 2000). High cover ( $>50 \%)$ can cause anoxia, while low cover ( 9 to $18 \%$ ) may produce little additional treatment effect (Winston et al., 2013). Usually, when the floating islands occupied $50 \%$ or more of the surface water area, the reduction in treatment efficiency due to anoxia was found in several studies (Borne et al., 2014).

For example, an almost complete coverage by islands resulted in poor P retention in sediments due to anoxia. Low $\%$ island cover had detrimental effects on treatment efficiency. TN removal was $48 \%$ with 9\% island cover in the Winston et al. (2013) study, but this increased to $88 \%$ TN removal with $18 \%$ cover. Similarly, Chang et al. (2013) found only $14 \%$ TP removal with $9 \%$ cover during storms, but outside of storm flows, this removal increased to $47 \%$. Around $20 \%$ cover seems optimal if the basin is to be maintained as an aerobic system without artificial aeration, and still achieve good removal efficiency. Beyond this point, it is probably worth using $100 \%$ cover, with a choice between a high nitrate removal anaerobic basins.

\subsubsection{Macrophytes}

Macrophytes offer a natural in situ system with relatively easy maintenance for AFIs.

Mechanisms involved in nutrient removal by aquatic macrophytes include incorporation of such macrophytes into their own system or storage in tissues (Wang et al., 2009). Plant species in AFI systems have different removal capacities of pollutants due to their specific biological properties such as uptake efficiencies for nutrients, growth rate and root types. Therefore, AFI systems 
175 vegetated with different aquatic species may show a great difference in the removal performance

176 of pollutants. For example, Zhang et al. (2014) found that microcosms planted with Scirpus

177 validus exhibited the greatest removal of TN, and those planted with Canna generalis showed a

178 large removal of nitrate nitrogen. In the research on AFI's purification in intensive aquaculture

179 ponds, water spinach (Ipomoea aquatica) floating bed had the highest direct absorption rates of

$180 \mathrm{TN}$ and TP; over 100 days, these were 52.35 and $5.39 \mathrm{~kg} \mathrm{hm}^{-2} \mathrm{a}^{-1}$, respectively (Chen et al., 2010).

181 Thus, Canna demonstrated a useful plant for sewage treatment, with its highest removal rates of $\mathrm{N}$

182 and $\mathrm{P}$ were 130 and $23 \mathrm{~kg} \mathrm{hm}^{-2} \mathrm{a}^{-1}$, respectively (Li et al., 2011). If the AFI was made up of

183 Canna and other plants, its removal rates of nitrogen and phosphorus would be much better, and

184 could reach 314.6 and $156 \mathrm{~kg} \mathrm{hm}^{-2} \mathrm{a}^{-1}$ (Zheng et al., 2013). We can conclude that Canna had the

185 greater capacities to remove nitrogen and phosphorus from the wastewater than other macrophytes.

186 However, to receive good removal efficiencies, the plants screened should also be based on the

187 longer lifetime, higher capacities of nutrients, and should be easy to harvest.

188 Meanwhile, planting density is also an important factor. High density of plants may increase

189 the removal rate, while the chlorophyll content of plants may decrease (Li et al., 2011). The best

190 density should depend on the plant species and the remediation goal. Li et al. (2011) planted

191 Ipomoea aquatica in eutrophied waters, and soluble protein content was higher and chlorophyll

192 content was low under high plant density. They reported very dense growth of Ipomoea aquatica

193 with 66 plants per floating bed in the area of $2 \mathrm{~m}^{2}$. In winter, under low temperature $8.5 \sim 10.5 \square$,

194 the density of 6 pots of Oenanthe javanica $/\left(0.08 \mathrm{~m}^{2}\right)$ of floating bed with $44.5 \%$ coverage had the

195 highest TN removal rate of $77.0 \%$, while the density of 10 pots $/\left(0.08 \mathrm{~m}^{2}\right)$ had the best TP removal

196 rate of $92.6 \%$. However, Oenanthe javanica should be harvested in a timely fashion as it could 
197

198

199

200

201

202

203

204

205

206

207

208

209

210

211

212

213

214

215

216

217

218

affect the water purification (Xiang and Peng, 2015).

Harvesting is essential for AFIs, although it can help with permanent removal of nutrients, but removal rates are typically low. The other reason is that, although shoot biomass tends to be larger than root biomass, there is generally more $\mathrm{N}$ and $\mathrm{P}$ stored in the roots than in the shoots, especially when autumn approaches (Winston et al., 2013). $\mathrm{N}$ is predominantly taken up by plants in the form of ammonia, but also as nitrate, while much of this is returned to the system when tissues senesce.

\subsubsection{Biofilm bacteria}

Biofilm bacteria are fixed mainly on the fiber fillers and plant roots in enhanced AFIs. An enhanced AFI is a type of ecological restoration strengthening device, composed mainly of microbial carrier packings and aquatic plants. The device uses the synergy of aquatic plants and microbes to complete the function of ecological restoration. At the same time, the biofilm bacteria can provide food for aquatic animals. The bacterial abundance was different with the change of

WT, pollutant concentration, bacteria metabolic activities and growth of plants. Stewart et al.

(2008) studied the microorganisms in municipal wastewater and the removal performances of ammonium and nitrate in floating islands without plant species, indicating that the floating islands with microorganisms had higher removals of both ammonium and nitrate than those without microorganisms. Sun et al. (2009) confirmed that the removal efficiency of nitrogen was greatly enhanced by adding the immobilized denitrifiers into water of floating islands. An enhanced AFI device vegetated with Canna was used to treat a eutrophic lake with hydraulic retention time efficiently within 4 days, where the bacteria were mainly attached on the fiber filling rather than the root surface, and the codominant species attaching to the filling and plant was 
219

220

221

222

223

224

225

226

227

228

229

230

231

232

233

234

235

236

237

238

239

240

Nitrosomonadaceae (Wu et al. 2016).

\subsubsection{Aquatic animals}

The introduction of aquatic animals can extend the food chain of floating-bed systems, and promote the dissociation of organic nitrogen and phosphorus compounds. It improves the biodegradability of particulate organic matters through the physiological activity of aquatic animals including filter-feeding, digestion and excretion, which meliorate the substrate-supplying condition for both plant absorption and biodegradation, resulting in an enhancement of the purification performance of AFI (Li et al., 2010). Nutrient removal from aquaculture effluent using floating islands ( $17 \%$ cover) planted with the aquatic Ipomoea aquatica was examined. Aeration was supplied for 1 hour at 6:00 AM every morning and the pond was populated with Aristichthys nobilis (silver carp), Siniperca chuatsi (mandarin fish; carnivorous) and Carassius auratus gibelio (crucian carp). Around $34 \%$ of the TN and $18 \%$ of the TP was removed from the system, and of this around one third (34\%) of TP and TN were removed by fish ( $\mathrm{Li}$ and $\mathrm{Li}, 2009)$.

Kania (2014, unpublished) also suggested sustainable growth of fish facilitated by AFI

significantly increases fish biomass that can be harvested from the waterway. Fish harvesting enables P removal from the effluent with fish being made into meal, which can be used for pork or poultry farming or in pet food. However, there must be no toxins or toxic metal contaminants in the effluent, especially contaminants that may bioaccumulate. Also, if it is to be sold for human consumption, the fish need to be cooked well, since there is the potential for contamination by pathogens.

\subsection{Heavy metals removal and the influence factors}

Removal and accumulation of various heavy metals by AFIs were shown below in a number 
241

242

243

244

245

246

247

248

249

250

251

252

253

254

255

256

257

258

259

260

261

262

of studies, including those cited below:

- Rivers and storm waters (e.g., Dushenkov et al., 1995; Agunbiade et al., 2009; Vesely et al., 2011; Chris et al., 2011; Zhao et al., 2012)

- Industrial wastewater treatment (e.g., Deng et al., 2004; Rai, 2009; Hegazy et al., 2011; Yadav et al., 2011)

\subsubsection{Macrophytes}

Noticeably, macrophytes are known to differ widely in their absorption of heavy metals depending on species. Mechanisms involved in metal removal by aquatic macrophytes are surface adsorption and/or absorption and its incorporation into their own system or storage in tissues in bound form. For example, Zhao et al. (2012) selected nine plants growing on an integrated AFI to remove nutrients and heavy metals in a river, and found that the top three plants regarding $\mathrm{Mg}$ content were frogbit (Hydrocharis dubia), water hyacinth (Eichhirnia crasslpes) and water lettuce (Pisitia stratiotes) within the range of $3.5-4.6 \mathrm{~g} \mathrm{~kg}^{-1}$, the plants with the top Fe content were pickerelweed (Pontederia cordata), frogbit (Hydrocharis dubia) and water dragon (Jussiaea reppens) within the range of $1.0-1.8 \mathrm{~g} \mathrm{~kg}^{-1}$, and the top Mn contents were water dragon (Jussiaea reppens), pennywort (Hydrocotyle verticillata) and pickerelweed (Pontederia cordata) among 6.7-3.6 $\mathrm{g} \mathrm{kg}^{-1}$, respectively. For Zn, the top three were water hyacinth (Eichhirnia crasslpes), pickerelweed (Pontederia cordata) and pennywort (Hydrocotyle verticillata) with a range of $0.12-0.17 \mathrm{~g} \mathrm{~kg}^{-1}$. The accumulation of trace elements in the tested plants was in the order of $\mathrm{Cu}>\mathrm{Pb}>\mathrm{Cr}>$ As. Similarly, Dong et al. (2014) found that the accumulation of trace elements in the nine tested plants was in the order of $\mathrm{Cu}>\mathrm{Pb}>\mathrm{Cd}$ growing in an AFI. The maximum $\mathrm{Cu}$ content of pickerelweed (Pontederia cordata) was $248.23 \pm 6.19 \mathrm{mg} \mathrm{kg}^{-1}$, and the plants with top Cd content 
263

264

265

266

267

268

269

270

271

272

273

274

275

276

277

278

279

280

281

282

283

284

within the range of 3.96-5.61 $\mathrm{g} \mathrm{kg}^{-1}$ were umbrella plant (Cypreus alternifolius) and pickerelweed

(Pontederia cordata). Pickerelweed (Pontederia cordata) was the macrophyte that removed the

highest concentration of heavy metals and its root accumulated the highest amount of heavy

metals.

\subsubsection{Aeration}

Aeration, as a controlling factor, is becoming more and more important, especially with micro-aeration. Overall, and different from nutrient removal mentioned above (100\% island cover of no aeration with a choice between a high nitrate removal anaerobic basin), micro-aeration is a very good choice for heavy metals removal. Aeration rate is controlled based on the initial concentration of heavy metals and their species. For example, different aeration rates have a certain ability to remove the $\mathrm{Cr}^{6+}$ in the sewage the concentration of $0.5 \mathrm{mg} \mathrm{L}^{-1}: 7.5 \mathrm{~L} \mathrm{~min}^{-1}>10 \mathrm{~L}$ $\min ^{-1}>5 \mathrm{~L} \min ^{-1}>2.5 \mathrm{~L} \mathrm{~min}^{-1}>0 \mathrm{~L} \mathrm{~min}^{-1}$. The $\mathrm{pH}$ of the influent was 7.1, and the WT was 11.5 $\square$, at the end of the experiment within 30 days, the final removal rates of the $0 \mathrm{~L} \mathrm{~min}^{-1}, 2.5 \mathrm{~L} \mathrm{~min}^{-1}, 5 \mathrm{~L}$ $\min ^{-1}, 7.5 \mathrm{~L} \mathrm{~min}^{-1}$ and $10 \mathrm{~L} \mathrm{~min}^{-1}$ of the AFI reached $61.28 \%, 68.24 \%, 74.58 \%, 78.52 \%$ and 75.68\%, respectively (Wu, 2015). Meanwhile, Chen et al. (2014) compared the removal efficiency of $\mathrm{Cu}^{2+}$ by a micro-aeration floating bed (aeration ratio $=2 \mathrm{~L} \mathrm{~min}^{-1}$ ), a combined floating bed and a traditional floating bed. The sewage initial concentration of $\mathrm{Cu}^{2+}$ was $1.24 \mathrm{mg} \mathrm{L}^{-1}$, after the 30 days experiment, the final removal rates of micro-aeration floating bed, combined floating bed, and traditional floating bed reached $87.21 \%, 69.21 \%$, and $59.82 \%$, respectively. The fast removal efficiency was within the first week.

\subsubsection{Endophytic bacteria}

Plant-associated bacteria isolated from the rhizoplane and phyllo plane surfaces are known as 
285

286

287

288

289

290

291

292

293

294

295

296

297

298

299

300

301

302

303

304

305

306

epiphytes, whereas those isolated from the interior of tissues, which they inhabit without causing harm to the host, are called endophytes, with some bacterial populations fluctuating between endophytic and epiphytic colonization (Compant et al., 2010). Rhizobacteria are the most studied plant-associated bacteria and are often found to have beneficial effects on plant growth, e.g., via the provision of essential elements, inhibition of colonization by pathogenic microorganisms, or by helping the plant to overcome stress responses to environmental insults (Afzal et al., 2014).

Further, certain endophytes are heavy metal hyperaccumulators, which can endure high concentrations of certain heavy metals, might have a distinct cell wall containing major functional groups because of their special growing environment, and are expected to be promising biosorbents (El-Deeb et al., 2012). For example, Guo et al. (2010) carried out experiments on endophytic bacteria Bacillus sp. L14 (EBL14) isolated from the Cd hyperaccumulator Solanum nigrum $\mathrm{L}$. The bioremediation potential of EBL14 was observed in the presence of $\mathrm{Cu}^{2+}, \mathrm{Cd}^{2+}$, and $\mathrm{Pb}^{2+}$ at a concentration of $10 \mathrm{mg} / \mathrm{L}$. Within 24 hours of incubation, EBL14 could specifically uptake $75.78,80.48$, and $21.25 \%$ of $\mathrm{Cd}^{2+}, \mathrm{Pb}^{2+}$, and $\mathrm{Cu}^{2+}$, respectively. In another study, from the same Cd hyperaccumulator S. nigrum L. plant, Microsphaeropsis sp. LSE 10 was isolated by Xiao et al. (2010) for biosorption of $\mathrm{Cd}^{2+}$, where the maximum biosorption capacity was $247.5 \mathrm{mg} / \mathrm{g}$.

\subsection{COD removal and the influence factors}

The main applications of AFIs in COD removal are mainly involved in the following:

- Rivers and storm waters (e.g., Ladislas et al., 2013; Huang et al., 2013)

- Industrial wastewater treatment (e.g., Bankston et al., 2002; Bokare et al., 2010)

- Livestock effluents (e.g., Hubbard et al., 2004; Nahlik and Mitsch, 2006)

Here, the chemical constituents of COD can, at time, be a mixture of compounds, which 
307

308

could be less or more toxic. Many researchers have found that the roots of aquatic plants in AFIs provide a space for microorganisms to grow on the plant stems and root surfaces, which can improve the removal of more toxic chemicals (Watson et al., 1989; Brix and Schierup, 1990; Tanner, 2001; Sooknah and Wilkie, 2004). More toxic chemicals usually come from industrial effluents. For example, triclosan (TCS) is widely used in products such as antiseptic soaps, toothpastes, fabrics, and plastics as a broad-spectrum antibacterial and antifungal agent (Bokare et al., 2010). Another chemical, trichloroethylene (TCE), is also a nonflammable, colorless liquid mainly used as a solvent to remove grease from metal parts (Bankston et al., 2002). Less toxic chemicals consist of normal suspended organic matters, and can be easily adsorbed and intercepted in biological grid devices and degraded by microorganisms. For example, in plant-bacteria associations, bacteria are capable of contributing toward overall pollutant removal by degrading complex organic pollutants from $3.5 \%$ to $70.6 \%$, with an inflow concentration of 55-99 mg/L (Wu et al., 2016).

\subsubsection{Endophytic bacteria}

The efficiency of AFIs can be improved by the use of certain pollutant-degrading bacteria (Newman and Reynolds, 2005; Weyens et al., 2013; Shehzadi et al., 2014; Ijaz et al., 2015). For example, Ijaz et al. (2015) studied the inoculation of three endophytic bacterial strains on the detoxification of sewage effluents in AFIs vegetated with Brachiaria mutica. The inoculated bacteria showed persistence in water as well as colonization in the root and shoot of the plant, and can be discharged in the environment without any environmental risks. Sun et al. (2009) also reported bacterially assisted Canna-carrying AFIs in sewage treatment. These studies provide useful evidences of endophyte-assisted AFIs to be a sustainable and affordable approach for in situ 
329

330

remediation of sewage effluents.

\subsubsection{Macrophytes}

The macrophytes and their rhizospheres may play important roles during phytoremediation.

For example, Huang et al. (2013) demonstrated the clear potential of floating bed

phytoremediation techniques by cultured Sesuvium portulacastrum for reducing organic pollution degree in brackish environment of the polluted Yundang Lagoon (southeastern China). The

floating bed experiment for phenol removal was carried out by Wang et al. (2015) and confirmed for phenol removal, the optimum conditions of Polygonum orientale were to have a $5 \mathrm{mg} \mathrm{L}^{-1}$ initial phenol concentration, $100 \%$ daylight, and a 12-day treatment time. The optimum conditions for Canna indica to remove phenol had a $2.5 \mathrm{mg} \mathrm{L}^{-1}$ initial phenol concentration, $100 \%$ daylight, and a 30-day treatment time. Meanwhile, $1 \mathrm{mg} \mathrm{L}^{-1}$ initial phenol concentration, $100 \%$ daylight, and a 16-day treatment time were the optimum conditions of Phragmites australis for phenol removal. For the removal of phenol, phenol concentration, light condition, and treatment time are three factors that had different impacts.

\section{Comparison between constructed wetlands and AFIs}

AFIs and constructed wetlands both have been acknowledged to contribute to the aesthetic quality of an area. However, there are advantages and possible problems when AFIs and constructed wetlands are compared (Wu et al., 2015; Ibekwe et al., 2016; Hu et al., 2016).

\subsection{Advantages and possible problems of AFIs}

AFIs are affordable methods of remediating wastewater as they do not require specifically designed experimental fields or instrumentations, which may save up to $80 \%$ of process energy and $50 \%$ of material input (Luederitz et al., 2001). Being a process based on the natural 
351

352

353

354

355

remediating power of plants and their associated microbes harbored on floating mats, AFIs are

also sustainable and environment-friendly as they can provide long-term remediation and pollutant

degradation with minimal environmental intervention. Other advantages of AFIs are their capability to cope with variations in water levels, their esthetic values, and provisions of habitats for invertebrates, fish, and birds (Keizer-Vlek et al., 2014).

However, certain efficient water purification plants can be dangerous to the innate ecosystem when introduced to the areas outside their native distribution areas (Vera et al., 2010). Improperly chosen and managed AFIs could cause undesirable influences on the local agriculture, aquaculture, and biodiversity due to invasive species. Further, the decayed, long soaked floating materials can also become a source of pollution (Yeh et al., 2015).

\subsection{Advantages and possible problems of constructed wetlands}

Constructed wetlands (CWs) have been widely employed since their first full-scale application in the late 1960s. Being similar to AFIs, CWs have extensively been applied to treat domestic sewages, agricultural wastewaters, industrial effluents, mine drainages, landfill leachates, urban runoffs, and polluted river waters in the last several decades because of their low-cost, easy-operation/maintenance (Wu et al., 2015).

However, CWs also have some intrinsic drawbacks that can limit their applications and long-term stabilities. Among them, substrate clogging is the biggest concern especially when CWs are used in wastewater treatment with high organic and suspended solid loading rates (Ruiz et al., 2010). Moreover, CWs sometimes have low nitrogen removal efficiencies; they may be nitrification limited as a result of low oxygen transfer or denitrification limited due to low amounts of available organics (Wu et al., 2014), especially under high nitrogen loading rates. 
373 Furthermore, some recalcitrant pollutants and heavy metals in industrial wastewater also present

374 challenges to the performance of CWs (Melián et al., 2008).

\section{4. Discussion and conclusions}

376

377
AFIs are innovative variant of wetlands, aquatic or terrestrial plants, growing in a hydroponic manner with buoyant frames floating on the surface of water bodies. Factors such as plant species, microbes, and physiochemical conditions are crucial for AFI operation to achieve sustainable treatment performances. Considering the successful and sustainable application of AFIs and constructed wetlands, the advantages and possible problems of AFIs and constructed wetlands are compared.

However, with the deteriorating environment and stringent discharge standards, including the emphasis on effluent reuse, AFI systems operating as stand-alone technologies are, in some cases, unable to meet the requirements of new guidelines despite of improvements in design and operational strategies and the utilization of intensified systems such as flow direction reciprocation, artificial aeration, tidal flow, etc. Thus, combining or integrating AFIs with other existent or emerging technologies, such as membrane bio-reactor (MBR), electrochemical oxidation, microbial fuel cells (MFCs) etc., may be an effective way forward, with the aim of maximizing the individual advantages in terms of wastewater treatment.

MBR technology is often utilized for advanced wastewater treatment to achieve water reclamation and reuse due to its simultaneous biological treatment and filtration effects. Moreover, MBR has the advantage of removing suspended solids, while simultaneously simplifying the whole treatment process by eliminating the need for a secondary clarifier when compared with conventional wastewater treatment processes (say activated sludge process) (Lin et al., 2013). 
395

396

397

398

399

400

401

402

403

404

405

406

407

408

409

410

411

412

413

\section{4}

415

416

However, MBRs can sometimes fail to achieve satisfactory removal of nutrients, especially when low-cost materials are used as the membrane module in order to reduce the investment (Khan et al., 2013). Therefore, there is a motivation to combine MBR technology with AFIs to simultaneously achieve low-cost operation while satisfying effluent quality demands. As such, the effluent of the MBR can be further polished in AFIs while the MBR, acting as "pre-treatment" step, could prolong their lifetime.

Since Liu et al. (2004) utilized the MFC technology to treat domestic wastewater; the studies for wastewater treatment and simultaneous energy extraction from organics-containing wastewaters have intensified. AFI system, especially with artificial aeration, can develop a significant redox gradient along its depth, i.e. aerobic environment at the upper part and anaerobic environment at the bottom of the water body. This redox distribution offers the possibility of integrating MFC technology into AFIs.

Further, the engineered bacteria should be studied more comprehensively for removing the specific pollutants without bringing risks to environment.

\section{Acknowledgement}

The authors are thankful to editors and reviewers for improving the manuscript, Dr.

Varenyam Achal for proofreading and editing the language. We also acknowledge Floating Island International, Inc. as the source of the Figure 1. This study was financially supported by Major

National Science and Technology Projects (2014ZX07101012).

\section{References}

Afzal, M., Khan, Q.M., and Sessitsch, A. 2014. Endophytic bacteria: prospects and applications for the phytoremediation of organic pollutants. Chemosphere. 117: 
417

418

232-242.

Agunbiade, F.O., Olu-Owolabi, B.I., and Adebowale, K.O. 2009. Phytoremediation potential of Eichornia crassipes in metal-contaminated coastal water. Bioresour Technol. 100: $4521-4526$.

Bankston, J.L., Sola, D.L., Komor, A.T., and Dwyer, D.F. 2002. Degradation of trichloroethylene in wetland microcosms containing broad-leaved cattail and eastern cottonwood. Water Res. 36: 1539-1546.

Bing, X.W., and Chen, J.C. 2001. The control of eutrophic water in ponds by floating-bed soilless culture of plants. Journal of Zhanjiang Ocean University. 21(3): 29-33.

Bokare, V., Murugesan, K., Kim, Y.M, Jeon, J.R., Kim, E.J., and Chang, Y.S. 2010. Degradation of triclosan by an integrated nano-bio redox process. Bioresour Technol. 101: 6354-6360.

Borne, K., Fassman-Beck, E., and Tanner, C.C. 2014. Floating Treatment Wetland influences on the fate of metals in road runoff retention ponds. Water Res. 48: 430-442.

Brix, H., and Schierup, H.H. 1990. Soil oxygenation in constructed reed beds: the role of macrophyte and soil-atmosphere interface oxygen transport. In: Cooper, P.F., Findlater, B.C. (Eds.), Constructed Wetlands in Water Pollution Control. Pergamon Press, New York, USA, 53-66.

Chang, N.B., Xuan, Z., Marimon, Z., Islam, K., and Wanielista, M.P. 2013. Exploring hydrobiogeochemical processes of floating treatment wetlands in a subtropical stormwater wet detention pond. Ecol. Eng. 54: 66-76.

Chang, Y.H., Ku, C.R., and Yeh, N. 2014. Solar powered artificial floating island for 

landscape ecology and water quality improvement. Ecol. Eng. 69: 8-16.

Chen, J.Z., Meng, S.L., Hu, G.D., Qu, J.H., and Fan, L.M. 2010. Effect of Ipomoea aquatica cultivation on artificial floating rafts on water quality of intensive aquaculture ponds. J. Ecol. Rural Environ. 26(2): 155-159.

Chen, Z., Fu, Y.S., and Zhang, Z.Q. 2014. Study on the removal efficiency of heavy metal copper using different types of ecological floating beds. Chin. Sci. Technol. Rev. 18: 134.

Chris, C.T., and Tom, R.H. 2011. Components of floating emergent macrophyte treatment wetlands influencing removal of stormwater pollutants. Ecol. Eng. 37(3): 474-486.

Compant, S., Clément, C., and Sessitsch, A. 2010. Plant growth-promoting bacteria in the rhizo- and endosphere of plants: their role, colonization, mechanisms involved and prospects for utilization. Soil Biol. Biochem. 42: 669-678.

Cui, D.C., and Hu, F. 2012. Bioremediation of WWTP effluent using an enhanced hybrid ecological bed under aeration condition. Water Saving Irri. 10: 18-20.

Deng, H., Ye, Z.H., and Wong, M.H. 2004. Accumulation of lead, zinc, copper and cadmium by 12 wetland plants species thriving in metal contaminated sites in China. Environ. Pollut. 132(1): 29-40.

Dong, X.X., Yan, C.Z., Wang, Z.S., Zhao, P.H., Zhou, S.L., and Wang, M. 2014. Removal efficiency and accumulation characteristics of $\mathrm{Cu}, \mathrm{Pb}$ and $\mathrm{Cd}$ in combined purification systems. Chin. J. Environ. Eng. 8(4): 1447-1453.

Dushenkov, V., Kumar, P., Motto, H., and Raskin, I. 1995. Rhizofiltration: the use of plants to remove heavy metals from aqueous streams. Environ. Sci. Technol. 29(5): 1239-1245. 
461

462

463

464

465

466

467

468

469

470

471

472

473

474

475

476

477

478

479

480

481

482

El-Deeb, B., Gherbawy, Y., and Hassan, S. 2012. Molecular characterization of endophytic bacteria from metal hyperaccumulator aquatic plant (Eichhornia crassipes) and its role in heavy metal removal. Geomicrobiol. J. 29(10): 906-915.

Guo, H., Luo, S., Chen, L., Xiao, X., Xi, Q., Wei, W., Zeng, G., Liu, C., Wan, Y., Chen, J., and He, Y. 2010. Bioremediation of heavy metals by growing hyperaccumulator endophytic bacterium Bacillus sp. L14. Bioresour Technol. 101: 8599-8605.

Harding, B. 2009. Biohaven floating islands. Inland scape SA. 2: 30-32. (http://www.floatingislandinternational.com/wp-content/plugins/fii/news/5.pdf).

Hegazy, A.K., Abdel-Ghani, N.T., and El-Chaghaby, G.A. 2011. Phytoremediation of industrial wastewater potentiality by Typha domingensis. Int. J. Environ. Sci. Technol. 8: $639-648$.

Hu, M.H., Yuan, J.H., Yang, X.E., and He, Z.L. 2010. Effects of temperature on purification of eutrophic water by floating eco-island system. Acta Ecol. Sin. 30(6): 310-318.

Hu, X.Q., Li, Z.H., Wang, C.X., Zheng, X.Q., and Ren, H.Y. 2008. Static experiments on purification of eutrophicated water body by complex ecological floating island. Journal of Hubei University (Natural Science). 30(3): 309-312.

Hu, Y., He, F., Ma, L., Zhang, Y., and Wu, Z.B. 2016. Microbial nitrogen removal pathways in integrated vertical-flow constructed wetland systems. Bioresour Technol. 207: 339-345.

Huang, L.F., Zhuo, J.F., Guo, W.D., Spencer, R.G.M., Zhang, Z.Y., and Xu, J. 2013. Tracing organic matter removal in polluted coastal wasters via floating bed phytoremediation. Marine Pollution Bulletin. 71(1-2): 74-82.

Hubbard, R.K., Anderson, W.F., Newton, G.L., Ruter, J.M., and Wilson, J.P. 2011. Plant 
483

484

485

486

487

488

489

490

491

492

493

494

495

496

497

498

499

500

501

502

503

504

growth and elemental uptake by floating vegetation on a single-stage swine wastewater lagoon. Trans. ASABE. 54(3): 837-845.

Hubbard, R.K., Gascho, G.J., and Newton, G.L. 2004. Use of floating vegetation to remove nutrients from swine lagoon wastewater. Trans. ASABE. 47(6): 1963-1972.

Huo, T., Wang, G.Y., and Ren, L. 2009. A study on impact of livestock and poultry breeding pollution on water environment safety in Shandong Province. Adv. Water Resour. Hydraul. Eng. 1(6): 525-530.

Ibekwe, A.M., Ma, J., Murinda, S., and Reddy, G.B. 2016. Bacterial community dynamics in surface flow constructed wetlands for the treatment of swine waste. Sci. Total Environ. 544: 68-76.

Ijaz, A., Shabir, G., Khan, Q.M., and Afzal, M. 2015. Enhanced remediation of sewage effluent by endophyte-assisted floating treatment wetlands. Ecol. Eng. 84: 58-66.

Islam, M.S., Ahmed, M.K., Raknuzzaman, M., Habibullah-Al-Mamun, M., and Islam, M.K. 2015. Heavy metal pollution in surface water and sediment: a preliminary assessment of an urban river in a developing country. Ecol. Indic. 48: 282-291.

Jeanette, L., Laurie, J.F., James, S.O.Jr., and David, J.S. 2015. Evaluation of commercial floating treatment wetland technologies for nutrient remediation of stormwater. Ecol. Eng. 75: 61-69.

Jin, X., and Hu, X. 2003. A comprehensive plan for treating the major polluted regions of Lake Taihu, China. Lakes Reservoirs: Res. Manage. 8: 217-230.

Kania, B.G., (n.d.). 2014. Bold Gold and Garney Green. Floating Island International. (http://www.floatingislandinternational.com/wp-content/plugins/fii/news/38.pdf.) 
505

506

Keizer-Vlek, H.E., Verdonschot, P.F., Verdonschot, R.C., and Dekkers, D. 2014. The contribution of plant uptake to nutrient removal by floating treatment wetlands. Ecol. Eng. 73: 684-690.

Khan, S.J., Ilyas, S., and Rehman, Z.U. 2013. Impact of nitrogen loading rates on treatment performance of domestic wastewater and fouling propensity in submerged membrane bioreactor (MBR). Bioresour Technol. 141: 46-49.

Ladislas, S., Gérente, C., Chazarenc, F., Brisson, J., and Andrès, Y. 2013. Performances of two macrophytes species in floating treatment wetlands for cadmium, nickel and zinc removal from urban stormwater runoff. Water Air Soil Pollut. 224: 1408.

Li, H.Y., Li, W.C., Feng, M.H., and Pan, J.Z. 2009. Characteristics and contribution of Oenanthe javanica uptake to nitrogen and phosphorus removal based on a micro-aerated ecological floating bed. J. Agro-Environ. Sci. 28(9): 1908-1913.

Li, H.Y., Yang, H.H., Ke, P., Peng, M.H., and Li, W.C. 2009. Purification effect and biofilm characteristics of micro-aerated ecological floating bed. Chin. Water Wastewater. 25(7): $35-40$.

Li, L., Yang, Y., Yang, F. J., and Pan, H. 2011. Growth characteristic features and behaviors of aquatic plants in the polluted water. J. Safety Environ. 11(3): 14-19.

Li, W., and Li, Z. 2009. In situ nutrient removal from aquaculture wastewater by aquatic vegetable Ipomoea aquatica on floating beds. Water Sci. Technol. 59(10): 1937-1943.

Li, X.N., Song, H.L., Li, W., Lu, X.W., and Nishimura, O. 2010. An integrated ecological floating-bed employing plant, freshwater clam and biofilm carrier for purification of eutrophic water. Ecol. Eng. 36: 382-390. 
527

528

Li, X.Y., Yang, Q.H., Meng, F.Q., Zhang, H., and Zhao, D. 2009. Function of loach on the pollutants removal from polluted river water using a BGD device. Chin. J. Appl. Environ. Bio. 15(1): 82-86.

Li, Y.Q., Li, Z.H., Jiang, Y.H., Wan, J., and Zhao, L.Y. 2011. Study on the changes of physiological indexes of water spinach in eutrophication water. J. Anhui Agri. Sci. 39(7): $4129-4131$.

Lin, H., Peng, W., Zhang, M., Chen, J., Hong, H., and Zhang, Y. 2013. A review on anaerobic membrane bioreactors: applications, membrane fouling and future perspectives. Desalination. 314: $169-188$.

Liu, H., Ramanarayanan, R., and Logan, B.E. 2004. Production of electricity during wastewater treatment using a single chamber microbial fuel cell. Environ. Sci. Technol. 38: $2281-2285$.

Liu, J.N., Wang, J.M., Zhao, C.C., Hay, A.G., Xie, H.J., and Zhan, J. 2016. Triclosan removal in wetlands constructed with different aquatic plants. Environ. Biot. 100(3): 1459-1467.

Lu, Q., He, Z. L.L., Graetz, D.A., Stoffella, P.J., and Yang, X.E. 2010. Phytoremediation to remove nutrients and improve eutrophic stormwaters using water lettuce (Pistia stratiotes L.). Environ. Sci. Pollut. Res. 17: 84-96.

Luederitz, V., Eckert, E., Lange-Weber, M., Lange, A., and Gersberg, R.M. 2001. Nutrient removal efficiency and resource economics of vertical flow and horizontal flow constructed wetlands. Ecol. Eng. 18: 157-171.

Luo, G.Y., Bu, F.P., Xu, X.Y., Cao, J., and Shu, W.Q. 2010. Effect of temperature on the ecological floating bed system. Chin. Environ. Sci. 30(4): 499-503. 
549 Melián, J.A.H., Araña, J., Ortega, J.A., Muñoz, F.M., Rendón, E.T., and Peña, J. P. 2008.

550 Comparative study of phenolics degradation between biological and photocatalytic

$551 \quad$ systems. J. Sol. Energy Eng. 130(4): 1-7.

552 Nahlik, A.M., and Mitsch, W.J. 2006. Tropical treatment wetlands dominated by free-floating macrophytes for water quality improvement in Costa Rica. Ecol. Eng. 28(3): 246-257.

Naichia, Y., Pulin, Y., and Yuan-Hsiou, C. 2015. Artificial floating islands for environmental improvement. Renewable Sus. Energy Rev. 14: 616-622.

Nduwimana, A., Yang, X.L., and Wang, L.R. 2007. Evaluation of a cost effective technique 
571

572

573

574

575

576

577

578

579

580

581

582

583

584

585

586

587

588

589

590

591

592

degradation of textile effluent in constructed wetland system using Typha domingensis and textile effluent-degrading endophytic bacteria. Water Res. 58: 152-159.

Shi, L.L., Cao, W.P., Cheng, Y.R., Han, X.R., and Huang, H. 2014. Performance and characteristics of different hybrid plants' ecological floating bed about purifying polluted water body with different matrix. Chin. Rural Water Hydr. 2: 13-17.

Smith, M., and Kalin, M. 2000. Floating wetland vegetation covers for suspended solids removal. Proceedings of the Quebec 2000: Millennium Wetland Event. Quebec City, Quebec, pp. 244.

Sooknah, R.D., and Wilkie, A.C. 2004. Nutrient removal by floating aquatic macrophytes cultured in anaerobically digested flushed dairy manure wastewater. Ecol. Eng. 22(1): $27-42$.

Stewart, F.M., Mulholland, T., Cunningham, A.B., Kania, B.G., and Osterlund, M.T. 2008. Floating islands as an alternative to constructed wetlands for treatment of excess nutrients from agricultural and municipal wastes-results of laboratory scale tests. Land Contam. Reclam. 16: 25-34.

Stiling, P.D. 2011. Ecology: Global Insights and Investigations. McGraw-Hill, New York.

Sun, L.P., Liu, Y., and Jin, H. 2009. Nitrogen removal from polluted river by enhanced floating bed grown Canna. Ecol. Eng. 35(1): 135-140.

Tanner, C.C. 2001. Plants as ecosystem engineers in subsurface-flow treatment wetlands. Water Sci. Technol. 44(11-12): 9-17.

Tuna, A.L., Yilmaz, F., Demirak, A., and Ozdemir, N. 2007. Sources and distribution of trace metals in the Saricay stream basin of southwestern Turkey. Environ. Monit. Assess. 125: 
593

594

595

596

597

598

599

600

601

602

603

604

605

606

607

608

609

610

611

612

613

614

47-57.

Vera, L.M., Davie, A., Taylor, J.F., and Migaud, H. 2010. Differential light intensity and spectral sensitivities of Atlantic salmon, European sea bass and Atlantic cod pineal glands ex vivo. Gen. Comp. Endocrinol. 165: 25-33.

Vesely, T., Tlustos, P., and Szakova, J. 2011. The use of water lettuce (Pistia stratiotes L.) for rhizofiltration of a highly polluted solution by cadmium and lead. Int. J. Phytoremediation. 13: 859-872.

Vymazal, J. 2007. Removal of nutrients in various types of constructed wetlands. Sci. Total Envir. 380: 48-65.

Wang, G.F., Wang, X.J., Wu, L., and Li, X.N. 2012. Contribution and purification mechanism of bio-components to pollutants removal in an integrated ecological floating bed. J. Civil Arch. Environ. Eng. 34(4): 136-141.

Wang, G.X., Zhang, L.M., Chua, H., Li, X.D., Xia, M.F., and Pu, P.M. 2009. A mosaic community of macrophytes for the ecological remediation of eutrophic shallow lakes. Ecol. Eng. 35: 582-590.

Wang, K., Cai, J., Xie, S.L., Feng, J., and Wang, T. 2015. Phytoremediation of phenol using Polygonum orientale and its antioxidative response. Archives Enviro. Protection. 41(3): $39-46$.

Watson, J.T., Reed, S.C., Kadlec, R.H., Knight, R.L., and Whitehouse, A.E. 1989. Performance Expactations and Loading Rates for Constructed Wetlands. In: Hammer, D.A. (Ed.), Constructed Wetlands for Wastewater Treatment.

Weyens, N., van der Lelie, D., Taghavi, S., and Vangronsveld, J. 2013. The poplar endophyte 
615

616

617

618

619

620

621

622

623

624

625

626

627

628

629

630

631

632

633

634

635

636

Pseudomonas putida W619 as a Key to a successful phytoremediation of volatile organic contaminants. In: de Bruijn, F.A. (Ed.), Molecular Microbial Ecology of the Rhizosphere. John Wiley and Sons, Inc., Hoboken, NJ, USA, 429-435.

Winston, R.J., Hunt, W.F., Kennedy, S.G., Merriman, L.S., Chandler, J., and Brown, D. 2013. Evaluation of floating treatment wetlands as retrofits to existing stormwater retention ponds. Ecol. Eng. 54: 254-265.

Wolverton, B.C., and Mcdonald, R.C. 1975. Water hyacinth and alligator weeds for removal of silver, cobalt and strontium from polluted waters. Nasa Technical Memorandum. 72: 727.

Wu, H.M., Zhang, J., Ngo, H.H., Guo, W.S., Hu, Z., Liang, S., Fan, J.J., and Liu, H. 2015. A review on the sustainability of constructed wetlands for wastewater treatment: Design and operation. Bioresour Technol. 175: 594-601.

Wu, L.J. 2015. Study on the removal efficiency of heavy metal-Cr( $\square$ ) in sewage using the micro-aerated strengthen ecological floating bed [D]. Chengdu: Southwest Jiaotong University.

Wu, M., Tang, X., Li, Q., Yang, W., Hua, F., Tang, M., and Sholz, M. 2013. Review of ecological engineering solutions for rural non-point source water pollution control in Hubei province, China. Water Air Soil Pollut. 224(5): 1561.

Wu, Q., Hu, Y., Li, S.Q., Sen, P., and Zhao, H.B. 2016. Microbial mechanisms of using enhanced ecological floating beds for eutrophic water improvement. Bioresour Technol. 211: 451-456.

Wu, S., Kuschk, P., Brix, H., Vymazal, J., and Dong, R. 2014. Development of constructed 
637

638

639

640

641

642

643

644

645

646

647

648

649

650

651

652

653

654

655

656

657

658

wetlands in performance intensifications for wastewater treatment: a nitrogen and organic matter targeted review. Water Res. 57: 40-55.

Wu, W., Song, X., Jin, Q., Ying, H., and Zou, G. 2000. Study on soilless cuture of Canna on fish pond. Chin. J. Applied Environ. Bio. 6: 206-210.

Xiang, W.Y., and Peng, Y. 2015. Remediation of eutrophic water by Oenanthe javanica eco-floating bed in Chongqing in winter. Chin. J. Environ. Eng. 9(11): 5393-5398.

Xiao, X., Luo, S., Zeng, G.,Wei, W.,Wan, Y., Chen, L., Guo, H., Cao, Z., Yang, L., Chen, J., and Xi, Q. 2010. Biosorption of cadmium by endophytic fungus (EF) Microsphaeropsis sp. LSE10 isolated from cadmium hyperaccumulator Solanum nigrum L. Bioresour Technol. 101: 1668-1674.

Xu, G.J., Duan, D.X., Du, X.H., Tian, G.T., Zhang, M.L., and Liu, F. 2015. Purification effect of combined ecological floating bed on aquaculture wastewater. J. Shanghai Ocean University. 24(1): 94-101.

Xu, H., Zhang, Y., Huang, M.S., Luo, J.H., and He, Y. 2011. Study on the effect of SFTWs for phosphorus removal from malodorous water. J. East China Normal University (Natural Science). 1: 119-125.

Yadav, B.K, Siebel, M.A., and van Bruggen, J.J.A. 2011. Rhizofiltration of a heavy metal (lead) containing wastewater using the wetland plant Carex pendula. Clean-Soil Air Water. 39: 467-474.

Yeh, N., Yeh, P., and Chang, Y.H. 2015. Artificial floating islands for environmental improvement. Renew. Sustain. Energy Rev. 47: 616-622.

Zhang, C.B., Liu, W.L., Pan, X.C., Guan, M., Liu, S.Y., Ge, Y., and Chang, J. 2014. 
659 Comparison of effects of plant and biofilm bacterial community parameters on removal 660 performances of pollutants in floating island systems. Ecol. Eng. 73: 58-63.

661 Zhang, R.B., Qian, X., Zheng, S.R., Yuan, X.C., and Xia, B.S. 2012. Purification efficiency of 662 lightly polluted water by vertical moveable eco-bed and ecological floating bed. Environ. 663 Chem. 31(11): 1705-1710.

664 Zhang, Z.S., Zhao, J.F., and Chen, L. 2011. Analyses on applicable technology of 665 CBPT-EEFR system of treatment for rural sewage. Sci. Res. 586-589.

666 Zhao, F.L., Xi, S., Yang, X., Yang, W.D., Li, J.J., Gu, B.H., and He, Z.L. 2012. Purifying 667 eutrophic river waters with integrated floating island systems. Ecol. Eng. 40: 53-60.

668 Zheng, Y.Z., Li, G., Du, J., Peng, C.R., and Liu, J.T. 2013. Effect of biological floating island 669 on water quality and algae in a tributary bay typical of the three-gorge reservoir. J. Ecol. $670 \quad$ Rural Envir. 29(3): 278-283. 


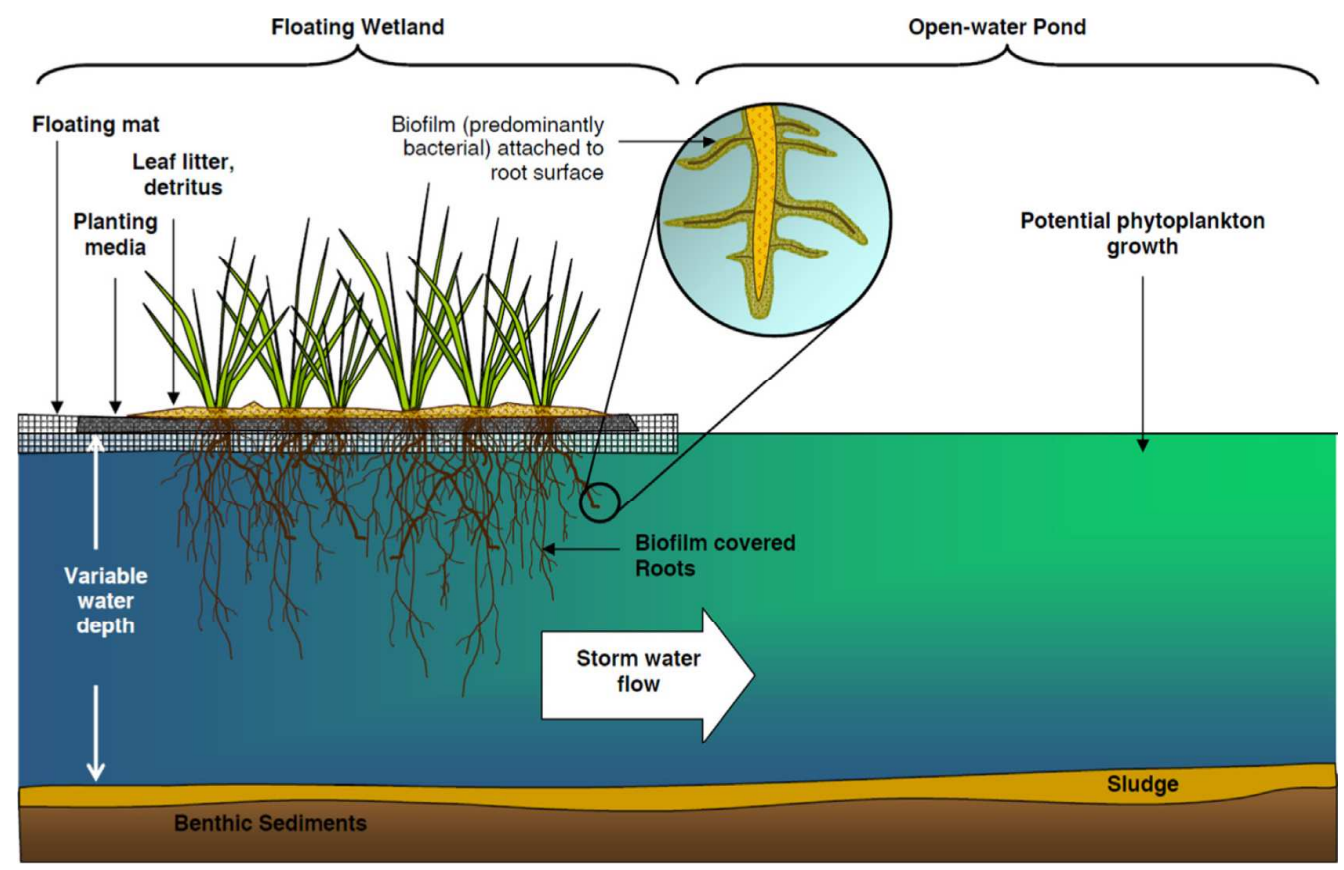

Fig. 1. Schematic of an artificial floating island (also called integrated floating treatment wetland or integrated ecological floating bed) (Harding, 2009) 